\title{
Vitae
}

33 (2018) 21-43

\section{Dawid Mielnik}

Katolicki Uniwersytet Lubelski Jana Pawła II, Lublin

mielnik.dawid@gmail.com, ORCID: 0000-0002-2701-4889

\section{Czym Mojżesz rozgniewa Boga? \\ PROBLEM PRZYCZYNY GNIEWU BOŻEGO \\ W NARRACJI WJ 4,24-26}

How Did Moses Make God Angry?

The Problem of God's Anger in Exodus 4:24-26

Celem niniejszej pracy jest ocena najważniej- obrzezanie; szych propozycji egzegetów usiłujących wytłu- Mojżesz; Sefora; maczyć przyczynę gniewu Bożego w narracji gniew; zabójstwo Wj 4,24-26. Autor przywołał i omówił cztery rozwiązania proponowane przez badaczy, które odniósł do omówionych we wcześniejszej części opracowania trudności generowanych przez kontrowersyjną perykopę. W świetle przeprowadzonych w pracy analiz należy stwierdzić, że żadne z przywołanych rozwiązań nie udziela zadowalających odpowiedzi na postawiony problem. W przypadku każdej propozycji bowiem pewne trudności pozostają nierozwiązane. Nie zmienia to jednak tego, że najlepszym wyjaśnieniem przyczyny gniewu Bożego wydaje się być odwołanie do nieobrzezania któregoś z bohaterów narracji. 
Chociaż ta propozycja słabo wpisuje się w kontekst perykopy, to jednak najlepiej radzi sobie $\mathrm{z}$ wewnętrznymi napięciami opowiadania.

The main purpose of this paper is an analysis and evaluation of the ideas of some major exegetes in their attempts to explain the reason for God's anger in the narrative of Exodus circumcision; Moses; Zipporah; angry; murder 4:24-26. The author first analyzes the difficulties generated by this problematic pericope, then lays out and examines the related propositions of four different researchers. Based on our investigation, we suggest that none of these scholarly treatments provides a satisfying answer to all the identified conundrums that emerge from the text. With each of the explanations, there are always some problems that remain unsolved. Despite this fact, the best understanding of God's anger here seems to be connected with the uncircumcised state of one character in the narrative. Although this idea links only weakly to the pericope's context, it still offers the best solution to the internal difficulties of the narrative.

\section{WPROWADZENIE}

Tajemnicza scena rozgrywająca się podczas podróży powrotnej Mojżesza do Egiptu w celu uratowania narodu wybranego z niewoli, krótko po powołaniu Mojżesza, jest jednym z najbardziej kontrowersyjnych fragmentów Pisma Świętego ${ }^{1}$. Głównym tego powodem jest bardzo trudna do poprawnego zinterpretowania wymowa tej sceny zarówno w odniesieniu

1 Por. Propp, „That Bloody Bridegroom”, 495. 
do niej samej, jak również w odniesieniu do kontekstu bliższego. Według tej narracji bowiem Bóg usiłuje pozbawić życia człowieka, którego dopiero co wybrał na wybawiciela swojego narodu, co wydaje się zarówno nieprawdopodobne, jak i nielogiczne. $Z$ drugiej strony perykopa ta, ze względu na wewnętrzny brak precyzji, sprawia tyle problemów egzegetom, że jej właściwe odczytanie napotyka na bardzo trudne do pokonania przeszkody, co w niemałej mierze spowodowane jest starożytnością opowiadania ${ }^{2}$.

Celem niniejszego opracowania jest ocena najważniejszych propozycji egzegetycznych usiłujących udzielić odpowiedzi na problem postawiony w tytule pracy. Osiągnięcie celu opracowania stanie się możliwe dzięki odniesieniu konkretnych propozycji interpretacyjnych do najważniejszych problemów generowanych przez kontrowersyjną narrację. W ten sposób będzie można stwierdzić, na ile dane rozwiązanie faktycznie radzi sobie z pojawiającymi się w perykopie problemami. Opracowanie składać się będzie z dwóch zasadniczych części. W pierwszej nastąpi przedstawienie trudności związanych z samą narracją oraz jej kontekstem bliższym. W drugiej będzie miało miejsce przedstawienie głównych kierunków wyjaśniających postawiony w temacie pracy problem oraz ich merytoryczna ocena pod kątem zarysowanych trudności.

\section{TRUdnośCi Kontekstualne}

I WEWNĘTRZNE PERYKOPY

Niejednoznaczna perykopa z Księgi Wyjścia, zdaniem egzegetów, dostarcza wielu problemów zarówno w odniesieniu do niej samej, jak również w odniesieniu do kontekstu, w którym aktualnie jest umiejscowiona $w$ ramach struktury narracji o wyjściu Izraelitów z Egiptu³. Przed dokonaniem właści-

2 Zob. Robinson, „Zipporah to the Rescue”, 447.

3 Por. Malina, „Dlaczego Bóg chciał zabić Mojżesza?”, 218. 
wych analiz należy najpierw ukazać trudności, z którymi borykają się badacze, zarówno co do kontekstu najbliższego opowiadania, jak i wewnętrznej narracji samego epizodu.

\subsection{Kontekst bliższy Wj 4,24-26}

Egzegeci są na ogół zgodni co do tego, że materiał zawarty w Wj 2-4, czyli w części, gdzie znajduje się problematyczna perykopa, jest kompilacją różnych źródeł pochodzących $z$ różnorodnych środowisk ${ }^{4}$. Sam urywek Wj 4,24-26 najczęściej wiązany jest z najstarszym źródłem Pięcioksięgu, czyli z tzw. tradycją jahwistyczną․ Kontrowersyjny fragment lokowany jest w ramach mniejszego zbioru tradycji, którego granice wyznacza się w 4,18-31. Ten zbiór ${ }^{6}$, określany jako opis powrotu Mojżesza do Egiptu, składa się z czterech mniejszych epizodów: wyruszenie w podróż (w. 18-20), instruktaż (w. 21-23), niebezpieczna przygoda w trakcie podróży (w. 24-26) oraz przybycie na miejsce (w. 27-31) ${ }^{7}$. Kontekstem poprzedzającym cały zbiór opowiadań jest opis teofanii na Horebie i powołanie Mojżesza (3,1-4,17), kontekstem następującym natomiast jest narracja o pierwszej konfrontacji $\mathrm{z}$ faraonem $(\mathrm{Wj}$ ).

Zdaniem egzegetów obecne miejsce kontrowersyjnej perykopy jest rezultatem późniejszej elaboracji. Na tle całej sekwencji wydarzeń przedstawionych od 3,1 do 4,31 epizod relacjonujący nocną napaść jawi się jako dodatek naruszający logikę opowiadania ${ }^{8}$. Nie jest bowiem logiczne, że Bóg,

4 Zob. Lemański, „Czy Jahwe”, 288.

5 Tę opinię potwierdzałyby obecne w tekście antropomorfizmy, korzystanie przez narratora $\mathrm{z}$ tetragramu oraz prymitywny charakter samego opowiadania.

6 Por. Plastaras, The God of Exodus, 102.

7 Niektórzy badacze w ramach ostatniego z wymienionych epizodów wyróżniają jeszcze część starszą (w. 29.31) i późniejszą (w. 27-28.30-31a). Zob. Seters, The Life of Moses, 69.

8 Por. Lemański, „Czy Jahwe”, 291. 
który dopiero co powołał Mojżesza do wykonania bardzo ważnej misji religijno-społecznej, krótko po tym akcie decyduje się go uśmiercić. W związku z tym perykopa 4,24-26 zapewne funkcjonowała jako niezależne opowiadanie, które dopiero na dalszym etapie redakcji Pięcioksięgu zostało włączone w obręb narracji'. Bardziej naturalnym miejscem dla problematycznej perykopy, jak sugerują niektórzy badacze ${ }^{10}$, wydaje się umiejscowienie jej pomiędzy opisem małżeństwa Mojżesza i jego powołaniem, czyli po fragmencie 2,21-22.

W kontekście bliższym perykopy 4,24-26 można zaobserwować pewne niekonsekwencje, dublety oraz obecność różnych uzasadnień tego samego wydarzenia. Tematycznie motyw spotkania obu braci wprowadzony w 4,27 łączy się bezpośrednio z narracją z 4,18-20. Instruktaż z 4,21-23 wydaje się przerywać naturalny bieg wydarzeń, jakim jest powrót Mojżesza do Egiptu, oraz stanowi pewne powtórzenie informacji z opisu powołania $(3,16-22)^{11}$. Niektórzy egzegeci podkreślają również, że z drugiej strony instruktaż z 4,21-23 wykazuje pewne podobieństwo z 7,9 oraz 11,10, czyli z opisami chronologicznie późniejszymi ${ }^{12}$.

Kolejny problem pojawia się w związku z fragmentem 4,18-19. W obecnym układzie tekstu prośba Mojżesza dotycząca uzyskania pozwolenia ze strony swego teścia na podróż następuje przed wyrocznią Bożą, w której Bóg nakazuje Mojżeszowi powrót oraz zapewnia o śmierci tych, którzy czyhali na jego życie. Bardziej logiczna byłaby odwrotna kolejność, to znaczy zamienienie miejscami wierszy 4,18 i 4,19,tak żeby sekwencja wydarzeń była odwrotna ${ }^{13}$. Warto również zauważyć, że teść Mojżesza, noszący w 4,18 imię

9 Zob. Lemański, Księga Wyjścia, 167.

10 Zob. Malina, „Dlaczego Bóg chciał zabić Mojżesza?”, 223.

11 Por. Seters, The Life of Moses, 65.Z drugiej strony trzeba zwrócić uwagę na oczywiste różnice pomiędzy obydwoma fragmentami, np. w 3,16-22 brakuje nawiązania do ostatniej plagi (śmierć pierworodnych).

12 Zob. Lemański, Księga Wyjścia, 167.

13 Por. Propp, Exodus 1-18, 195. 
Jetro, jest tak nazywany dopiero od 3,1, wcześniej natomiast $(2,18)$ określony został terminem Reuel ${ }^{14}$.

Dokładniejsza analiza epizodu przedstawionego w 4,18-20 pozwala zauważyć różne motywy związane z decyzją Mojżesza o powrocie do Egiptu ${ }^{15}$. Według 4,18 Mojżesz prosi swego teścia o zgodę na opuszczenie go, motywując to chęcią odwiedzenia swoich pobratymców. Jest to cel podróży oficjalnie deklarowany Jetro. Wiersz 4,19 z kolei przytacza mowę Bożą skierowaną do Mojżesza, w której powodem podjęcia podróży ma być śmierć tych, którzy zamierzali go zabićc ${ }^{16}$. Wreszcie, z opisu powołania Mojżesza $(3,1-4,17)$ wynika, że zasadniczym celem jego podróży ma być wyprowadzenie Izraela z niewoli egipskiej $(3,10)$. Niektórzy egzegeci zauważają nawet, że innym powodem wyprawy Mojżesza mogła być pobudka osobista - chęć zobaczenia się z bratem $(4,14)^{17}$.

$\mathrm{Na}$ końcu należy zwrócić uwagę na problem związany z najbliższą rodziną Mojżesza. Jego małżeństwo z Seforą, jedną z córek madianickiego kapłana, zostało wspomniane w 2,21. Za chwilę również narrator umieścił informację o narodzinach syna Mojżesza oraz wyjaśnił etymologię imienia Gerszoma (w. 22). Później narracja nie będzie już powracać do wątku założonej przez Mojżesza rodziny aż do 4,20. Według zawartej tam informacji Mojżesz zabrał ze sobą w podróż żonę oraz synów. Ta wzmianka jest o tyle problematyczna, że narracja nie wprowadziła, jak dotąd, obok Gerszoma żadnego innego syna Mojżesza ${ }^{18}$. Jeszcze większy kłopot pojawia się w związku z próbą ustalenia, co działo się z Seforą i jej dziećmi przed wydarzeniami opisanymi w 18,1-6. Według logiki narracji należałoby przyjąć, że Sefora

14 To określenie teścia Mojżesza powróci jeszcze w Lb 10,29. Imię Jetro natomiast występuje w $\mathrm{Wj} 3,1 ; 4,18 ; 18,1.2 .5 \cdot 6.9 .10 .12$.

15 Por. Seters, The Life of Moses, 64.

16 W tym wersecie pojawia się partykuła kî wprowadzająca najczęściej zdania przyczynowe.

17 Zob. Malina, „Dlaczego Bóg chciał zabić Mojżesza?”, 226.

18 Por. Lemański, „Czy Jahwe”, 290. 
wraz z Gerszomem i Eliezerem ${ }^{19}$ nie w rócili z Mojżeszem do Egiptu, co kłóciłoby się z informacją podaną w rozdziale czwartym ${ }^{20}$.

\subsection{Wewnętrzne nieścisłości perykopy}

Sam podział perykopy nie sprawia większych trudności. Problematyczną narrację można ustrukturyzować w trzech zasadniczych częściach: informacja o napaści (w. 24), opis postępowania Sefory i skutku jej aktywności (w. 25-26a) oraz komentarz (w. 26b) ${ }^{21}$. Tłumaczenie tej perykopy również nie sprawia zbyt wielkich problemów. Trudności pojawiają się natomiast w odniesieniu do poprawnego zidentyfikowania bohaterów opowiadania, właściwego odczytania wykorzystanych w tekście zaimków osobowych, bezbłędnej interpretacji czynności Sefory i adresata jej wypowiedzi, poprawnego zrozumienia wyrażeń regālîm (w. 25), hătan-dāmîm (w. 25-26) i partykuły 'āz (w. 26) oraz właściwego wytłumaczenia powodu dwukrotnego powtórzenia tych samych słów przez Seforę. Problemy pojawiające się na poziomie tekstu hebrajskiego próbowały już rozwiązywać najstarsze tłumaczenia: Septuaginta oraz przekłady syryjskie.

$\mathrm{Na}$ podstawie tekstu źródłowego bezbłędnie można zidentyfikować jedynie dwóch bohaterów opowiadania: Boga (w. 24) oraz Seforę (w. 25), ponieważ ich imiona wprost pojawiają się w narracji. Co więcej, 4,25 wspomina o synu Sefory, który jednak nie został w tekście wymieniony z imienia. $\mathrm{Na}$ podstawie informacji zawartych $\mathrm{w} \mathrm{Wj}$ 18,1-4 należy przypuszczać, że owym synem jest Gerszom albo Eliezer. W oparciu o tekst hebrajski kontrowersyjnej narracji nie można jednoznacznie rozstrzygnąć problemu obecności Mojżesza w pe-

19 Imię drugiego syna Mojżesza zostaje wprowadzone dopiero w Wj 18,4.

20 Por. Seters, The Life of Moses, 65. Innym interesującym problemem jest kwestia tożsamości żony Mojżesza, o której mowa w Lb 12,1.

21 Zob. Lemański, „Czy Jahwe”, 295. 
rykopie 4,24-2622. Imię Mojżesza nie pojawia się również w Septuagincie. Dopiero przekłady syryjskie Pisma Świętego w 4,24 wyraźnie przywołują imię Mojżesza, i to dwukrot$n^{23}{ }^{23}$. Septuaginta $z$ kolei nie umieszcza w narracji Boga, ale zastępuje Jego osobę aniołem Pańskim ${ }^{24}$.

W źródłowym tekście perykopy 4,24-26 jest jeden zaimek osobowy (w. 25) oraz sześć sufiksów zaimkowych występują$\mathrm{cych}^{25}$, zgodnie z regułami gramatycznymi języka hebrajskiego, jako sufiksy zaimkowe czasowników, rzeczowników i przyimków. Identyfikację jedynie dwóch z nich można uznać za pewną. Niebudzące większych wątpliwości jest odniesienie sufiksu zaimkowego trzeciej osoby singularis femininum przy słowie bèn (w. 25). Kontekst wskazuje, że ten zaimek należy odnieść do Sefory. Drugą pewną identyfikacją jest sufiks zaimkowy pierwszej osoby singularis dołączony do przyimka lo (w. 25). On również odnosi się do Sefory, ponieważ to ona jest autorem wypowiedzi, w której ów sufiks zaimkowy się pojawia.

Identyfikacja pozostałych zaimków dzierżawczych występujących w kontrowersyjnej narracji jest już problematyczna i nie taka oczywista. W 4,24 dwukrotnie powraca sufiks zaimkowy trzeciej osoby singularis masculinum. $\mathrm{Za}$ pierwszym razem pojawia się on przy czasowniku wyprowadzonym z korzenia $p g s$, za drugim razem - przy formie zbudowanej na rdzeniu $m w t^{26}$. Na podstawie treści perykopy i jej kontekstu bliższego jest zasadne wskazanie trzech osób, do których te zaimki mogą się odnosić: Mojżesza, Gerszoma albo Eliezera. Kolejnym niejednoznacznym dla poprawnej interpretacji zaimkiem jest sufiks zaimkowy

22 O jego uczestnictwie w opisanych wydarzeniach można wnioskować jedynie na podstawie kontekstu bliższego perykopy.

23 Por. Dumbrell, „Exodus 4:24-26”, 285.

24 Księga Jubileuszów zaś atak na Mojżesza przypisuje Mastemie (48,1-4). Por. Lemański, „Szatan i inni”, 176-177.

25 Dwa w 4,24, trzy w 4,25 oraz jeden w 4,26.

26 Określenie podmiotu dla tych czasowników nie sprawia kłopotu, gdyż wykonawca tych czynności został podany przez narratora. 
trzeciej osoby singularis masculinum dołączony do liczby mnogiej rzeczownika regel (w. 25). Podobnie jak to miało miejsce w poprzednio opisanym przypadku, $\mathrm{w}$ świetle logiki opowiadania i kontekstu bliższego perykopy można podać racje za odniesieniem go do Mojżesza, Gerszoma lub Eliezera ${ }^{27}$. Ostatni problematyczny dla właściwego zrozumienia narracji zaimek pojawia się w 4,26 jako sufiks zaimkowy trzeciej osoby singularis masculinum przy przyimku min. Ponownie logika narracji prowadziłaby do przyjęcia, że desygnatem tego zaimka może być Mojżesz lub jeden z jego synów. Równie trudne jest właściwe odniesienie jedynego zaimka osobowego występującego w kontrowersyjnej perykopie $^{28}$. W tym przypadku zakres potencjalnych osób, do których można odnieść ów zaimek jest jeszcze większy ${ }^{29}$. Może to być Mojżesz, Gerszom, Eliezer albo Bóg.

W odniesieniu do dwóch zaimków dzierżawczych z 4,24 wymowę tekstu precyzują tłumaczenia syryjskie, w których wyraźnie zostaje wprowadzone imię Mojżesza, co umożliwia dokładne określenie desygnatu owych dwóch zaimków ${ }^{30}$. Tłumacze Septuaginty z kolei wprowadzają istotne korekty w 4,25. Translatorzy nie uwzględniają zaimka dzierżawczego przy słowie „nogi” ${ }^{31}$ oraz pomijają zaimek osobowy, co po-

27 Warto jednak zauważyć, że w świetle sekwencji poszczególnych elementów zdania należałoby odnieść ten zaimek do desygnatu wyrażenia „jej syna” (w. 25), czyli do Gerszoma albo Eliezera. Nie można również wykluczyć, co jest jednak mniej prawdopodobne, że ów zaimek może odnosić się do Boga przedstawionego w tym opowiadaniu kategoriami antropomorficznymi. Por. Kłoczkowski, „Dlaczego Bóg”, 9. Jest to zaimek drugiej osoby singularis masculinum.

29 Zaimek ten jest podmiotem orzecznika hătan-dāmîm. Zatem desygnatem tego zaimka jest osoba, do której odnosi się wyrażanie hătan-dāmîm.

30 Por. Malina, „Dlaczego Bóg chciał zabić Mojżesza?”, 220.

31 Dotknięcie przez Seforę napletkiem nóg zostaje w Septuagincie zastąpione aktem adoracji, przy opisie którego translatorzy zdecydowali się nie wykorzystywać zaimka dzierżawczego odniesionego do słowa „nogi”. 
woduje zlikwidowanie problemów interpretacyjnych w odniesieniu do określenia desygnatów zaimków z tego wersetu. Pięcioksiąg samarytański natomiast posiada inną lekcję zaimka dzierżawczego z 4,26. Zamiast lekcji mimmennû występuje wariant mimmennâ, co sugeruje, że chodzi o Seforę.

W obliczu nadchodzącego niebezpieczeństwa małżonka Mojżesza dokonuje czterech czynności. Po pierwsze, bierze ostry kamień. Po drugie, przy pomocy tego narzędzia dokonuje obrzezania swojego syna ${ }^{32}$. Po trzecie, odciętym napletkiem dotyka czyichś nóg. Wreszcie wypowiada specjalną formułę, która towarzyszy wykonaniu trzeciej z wymienionych czynności. O ile dwie pierwsze aktywności Sefory nie sprawiają większego problemu egzegetom, o tyle $\mathrm{z}$ dwoma następnymi związana jest seria niejasności i wątpliwości.

Trzecia z wymienionych czynności nie została w tekście źródłowym sprecyzowana w zakresie jej adresata. Oznacza to, że na podstawie wariantu hebrajskiego trudno jest jednoznacznie ustalić, czyich nóg Sefora dotknęła odciętym napletkiem. Uwzględnienie całej perykopy pozwala tak naprawdę wskazać trzy potencjalne osoby: Gerszoma, Eliezera lub Mojżesza ${ }^{33}$. Problematyczna jest również tak naprawdę właściwa interpretacja części ciała, którą dotknęła napletkiem Sefora. Hebrajski termin regālîm może bowiem, obok desygnatów 'nogi, stopy', być wykorzystywany jako eufemizm na określenie narządów płciowych (Sdz 3,24; 1 Sm 24,4) ${ }^{34}$. Tłumacze Septuaginty zmienili sens tekstu źródłowego. W greckim przekładzie Sefora nie tyle dotyka obciętym napletkiem czyichś nóg, ile raczej pada przed stopami anioła Pańskiego ${ }^{35}$.

Słowa wypowiedziane przez małżonkę Mojżesza również sprawiają wiele problemów egzegetom. Szczególnie doty-

32 Należy podkreślić, że autor natchniony nie pisze wprost, że Sefora obrzezała swojego syna, ale że obcięła jego napletek. Por. Baranowski, „Dlaczego Bóg chciał zabić Mojżesza”, 78.

33 Nie jest również wykluczona osoba Boga.

34 Por. Lemański, „Czy Jahwe”, 302.

35 Por. Malina, „Dlaczego Bóg chciał zabić Mojżesza?”, 220-221. 
czy to wyrażenia hătan-dāmîm, które powraca dwukrotnie $\mathrm{w}$ analizowanej perykopie. Za każdym razem pada ono z ust Sefory (w. 25 i 26). Choć znaczenie terminu hătan samo w sobie jest zrozumiałe ${ }^{36}$, to jednak właściwe zaadoptowanie go w tej konkretnej narracji nie jest już takie oczywiste. $\mathrm{Za}$ najbardziej prawdopodobne uznaje się tłumaczenie tego terminu w wypowiedzi Sefory jako 'pan młody, oblubieniec', niemniej przy uwzględnieniu informacji zawartych ${ }_{\mathrm{w}} \mathrm{Wj}$ 2,21-22 nawet takie odczytywanie terminu hătan nie jest pewne ${ }^{37}$. Tłumacze Septuaginty zrezygnowali z niejasnego wyrażenia, zmieniając całkowicie sens wypowiedzi żony Mojżesza i czyniąc z nich bardziej gest natury ofiarniczej ${ }^{38}$.

Związek pomiędzy odstąpieniem Boga a powtórnym wypowiedzeniem przez Seforę trudnych do poprawnego zinterpretowania słów również nie jest do końca jasny wskutek wykorzystania przez narratora partykuły 'àz. To słowo bowiem może wprowadzać następstwo czasowe albo logiczne ${ }^{39}$. Tłumacze Septuaginty, wskutek użycia słowa dioti, interpretowali tę partykułę w kategoriach następstwa logicznego ${ }^{40}$. Kwestia dwukrotnego pow tórzenia przez Seforę tego samego wyrażenia jest kolejnym problemem dla egzegetów. Tekst źródłowy, choć powtarza dwa razy wyrażenie hătan-dāmîm, to jednak w pierwszej wypowiedzi małżonki Mojżesza jest ono osadzone

36 Terminem tym określa się osobę, która wchodzi w relacje rodzinne z krewnymi współmałżonka. To słowo może zatem oznaczać zięcia, teścia lub pana młodego (Rdz 19,14; Wj 3,1; Iz 62,5). Por. Lemański, Ksiega Wyjścia, 172.

37 Trudno jest nazywać Mojżesza panem młodym przy założeniu, że to do niego odnosi się to wyrażenie, skoro nie dość, że minęło już sporo czasu, odkąd się ożenił, to jeszcze na dodatek ma dzieci.

38 Por. Lemański, „Czy Jahwe”, 292.

39 Od interpretacji tej partykuły zależy to, czy powtórne wypowiedzenie przez Seforę przytoczonej przez narratora formuły po prostu miało miejsce po odstąpieniu Boga czy może odejście niespodziewanego Gościa było przyczyną wypowiedzenia przez małżonkę Mojżesza określonych słów.

40 Zob. Malina, „Dlaczego Bóg chciał zabić Mojżesza?”, 220. 
w nieco innym kontekście niż w drugiej, gdzie przywołane wyrażenie wyraźnie jest łączone z dokonanym przez Seforę obrzędem obrzezania. Pierwsi tłumacze Pisma Świętego na język grecki zdecydowali się na dwukrotne włożenie takiego samego zdania w usta Sefory, wskutek czego obie wypowiedzi małżonki Mojżesza nie różnią się absolutnie niczym względem siebie, ale znacząco wobec tekstu hebrajskiego ${ }^{41}$.

\section{GŁÓWNE KIERUNKI WYJAŚNIANIA POSTAWY BOGA W WJ 4,24}

Zamiar uśmiercenia Mojżesza przez Boga już od starożytności próbowano wytłumaczyć na różne sposoby, co potwierdza, że już od najdawniejszych czasów owa perykopa stanowiła problem dla komentatorów zarówno chrześcijańskich, jak również żydowskich. Wśród różnych prób interpretacji postawy Boga z Wj 4,24 cztery wydają się najbardziej przekonujące. Pierwsza z nich przyczynę interwencji Bożej dostrzega w nieobrzezaniu Mojżesza lub jednego z jego synów. Druga kontrowersyjną perykopę próbuje tłumaczyć przez odwołanie się do dokonanego przez Mojżesza zabójstwa Egipcjanina. Trzecia z nich wystąpienie Boga wiąże z naganną postawą Mojżesza podczas powołania. Czwarta natomiast odwołuje się do późniejszych wydarzeń paschalnych, widząc w perykopie 4,24-26 ich antycypację ${ }^{42}$.

41 Zastosowanie terminu dioti pozwoliło na umiejętne wytłumaczenie przez tłumaczy powtórzenia zdania. W przekładzie Septuaginty, dzięki obecności właśnie tego słowa, druga wypowiedź Sefory jest tożsama z pierwszą - pierwsza część 4,26 wprowadza właśnie wyjaśnienie słów małżonki Mojżesza z 4,25. Por. Childs, The Book of Exodus, 99.

42 Wśród innych prób tłumaczenia wystąpienia Boga wymienia się np. chęć złożenia przez Mojżesza ofiary z własnego syna. Zob. Lemański, „Czy Jahwe”, 298. 


\subsection{Zaniedbanie obrzezania}

Próba tłumaczenia szokującego zachowania Boga z Wj 4,24 brakiem obrzezania któregoś z bohaterów narracji jest chyba najczęściej powracającym wyjaśnieniem badanej perykopy ${ }^{43}$. Taka interpretacja podtrzymywana była już od czasów starożytnych zarówno przez autorów chrześcijańskich ${ }^{44}$, jak również żydowskich ${ }^{45}$. Przyjęcie tej drogi interpretacyjnej stwarza jednak kolejny problem, mianowicie pojawia się pytanie o to, kto nie został obrzezany. W świetle samej narracji oraz jej najbliższego kontekstu możliwe wydają się tylko trzy odpowiedzi. Nie był obrzezany Mojżesz, Gerszom lub Eliezer $^{46}$. Możliwy jest również taki wariant, co niektórzy przyjmują ${ }^{47}$, że nieobrzezanych było więcej osób.

Prawdopodobieństwo, że to Mojżesz nie został obrzezany, wydaje się mniej prawdopodobna od pozostałych opcji ${ }^{48}$.

43 Zdaniem niektórych egzegetów w ogóle celem tej narracji jest wiązanie zwyczaju obrzezania z osobą Mojżesza bądź uzasadnieniem przejścia praktykowania tego obrzędu z okresu przedślubnego na okres dziecięcy. Zob. Childs, The Book of Exodus, 97; Murphy, The Book of Exodus, 13; Frolov, „The Hero as Bloody Bridegroom”, 520.

44 Tak uważali np. Tertulian, Hipolit, Orygenes, Ambroży, Augustyn oraz Grzegorz z Nyssy. Zob. Tertullianus, Liber adversus Judaeos, 3; Hippolytus, Commentarius in Danielem, 4, 40; Origenes, Commentarium in epistolam beati Pauli ad Romanos, 2, 13, 39; Ambrosius, In Psalmum David CXVIII Expositio, 16, 11; Augustinus, Epistolae, 23, 4; Augustinus, Quaestionum in Heptateuchum Libri Septem, 2, 11; Augustinus, Quaestiones veteris et novi testamenti, 16; Gregorius Nyssenus, De vita Moysis, 1, 22. Wszyscy oni przyjmowali, że nieobrzezany był syn Mojżesza. Taką opinię można również przypisać Epifaniuszowi z Salaminy. Zob. Epiphanius, Panarion, 30, 27.

45 Według Targumu Pseudo-Jonatana nieobrzezany był Gerszon, gdyż na ten obrzęd miał nie zgodzić się Jetro. Eliezer zaś był obrzezany za obopólną zgodą jego i Mojżesza. Tak samo wypowiada się na ten temat Targum Neofiti.

46 Zob. Łach, Ksiegga Wyjścia, 313.

47 Tak czyni np. Allen, „The «Bloody Bridegroom»”, 263.

48 Chociaż niektórzy opowiadają się za taką ewentualnością. Zob. Craghan, Exodus, 20. 
Przede wszystkim obrzezanie Mojżesza sugeruje w sposób pośredni perykopa Joz 5,2-7 opowiadająca o dokonaniu obrzezania całego pokolenia Izraela ${ }^{49}$. Innym przywoływanym argumentem jest spostrzeżenie, że Egipcjanie również praktykowali obrzezanie, co potwierdza tekst Jr 9,24-25. W świetle tych spostrzeżeń za bardziej prawdopodobną należy uznać tezę, że nieobrzezany był któryś z synów Mojżesza ${ }^{50}$. Ponieważ narracja wspomina o obrzezaniu przez Seforę tylko jednego chłopca, należałoby na tej podstawie przyjąć, że drugi syn Mojżesza był obrzezany. W takim razie bardziej prawdopodobne wydaje się twierdzenie, że nieobrzezany był mlodszy syn.

Niemniej przyjęcie takiej interpretacji nie rozwiązuje wszystkich problemów związanych z samą perykopą. Ciągle bowiem nie ma pewności, kto jest desygnatem sufiksów zaimkowych z 4,24: Mojżesz czy jego nieobrzezany syn. Wciąż również nie jest jednoznaczne, czyich nóg Sefora dotknęła odciętym napletkiem ani do kogo skierowała przytoczone przez narratora słowa. Lepszego wyjaśnienia nie otrzymuje również samo wyrażenie ḥătan-dāmîm ani sens jego powtórzenia w nieco zmienionej formie ${ }^{51}$. Wreszcie jedną z najsłabszych stron tej interpretacji jest brak bezpośredniego osadzenia w wydarzeniach przedstawionych w bliższym i dalszym kontekście perykopy 4,24-26, gdzie do kwestii nieobrzezania Mojżesza lub jego syna nie czyni się żadnych nawiązań ${ }^{52}$.

49 Tekst wyjaśnia, że wszyscy mężczyźni „zdolni do noszenia broni” spośród tych, którzy opuścili Egipt, zostali obrzezani. To zdanie wskazuje na to, że obrzezanie było praktykowane wśród Izraelitów w Egipcie.

50 Według Orygenesa był to Eliezer. Zob. Origenes, Contra Celsum, 5,48 .

51 Niekiedy pojawiają się sugestie, że słowa wypowiedziane przez Seforę były być może formułą wypowiadaną podczas obrzezania. Zob. Łach, Ksiega Wyjścia, 315.

52 Znamienne jest również to, że nawet w dialogu Mojżesza z Bogiem podczas powołania nie ma żadnych aluzji do tego, żeby brak obrzezania miał być powodem Bożej interwencji. 
Solidną stroną takiego tłumaczenia interwencji Bożej jest natomiast mocne osadzenie w samej narracji. Czynności Sefory stają się wtedy o wiele bardziej zrozumiałe, a podanie powodu odstąpienia Boga od realizacji powziętego zamiaru nie sprawia już żadnych problemów. Przyjęcie chwilowej niedyspozycji Mojżesza, jak proponują niektórzy, tłumaczyłoby również, dlaczego to Sefora dokonała obrzędu obrzezania, a nie jej małżonek. Przy takiej interpretacji Bóg czułby się zmuszony interweniować, ponieważ Mojżesz, jako osoba, która miała wybawić Izrael, powinna odznaczać się absolutną wiernością Stwórcy i Jego prawom, a brak obrzezania mógłby uchodzić za znak niewierności powołanego ${ }^{53}$.

\subsection{Zabójstwo Egipcjanina}

Kolejną propozycją przedstawianą przez egzegetów jest łączenie omawianej narracji z wydarzeniem opisanym w Wj 2,11-12. Według tego tekstu Mojżesz, przebywając jeszcze w Egipcie, był świadkiem znęcania się Egipcjanina nad Izraelitą. Stając w obronie krzywdzonego rodaka, Mojżesz zdecydował się na zabicie prześladowcy. Zwolennicy tej linii tłumaczenia przyczyny Bożej interwencji z narracji 4,24-26 zauważają, że Mojżesz, wskutek dopuszczenia się zabójstwa, zaciągnął winę, która zgodnie z zasadą odpłaty powinna zostać pomszczona przez mściciela określanego na kartach Starego Testamentu terminem gōe el $\left.\right|^{54}$. Rolę owego mściciela miałby przejąć właśnie Bóg, który usiłuje pomścić zabitego Egipcjanina w omawianej perykopie.

Pytanie, które w sposób naturalny pojawia się w związku z taką interpretacją, dotyczy tego, dlaczego Bóg miałby czekać na pomszczenie zabitego tak długo, a nie mógł tego uczynić wcześniej, np. przed powołaniem Mojżesza. Tekst biblijny nie udziela na to pytanie żadnej bezpośredniej od-

53 Zob. Allen, „The «Bloody Bridegroom»”, 266.

54 Zob. Baranowski, „Dlaczego Bóg chciał zabić Mojżesza”, 78. 
powiedzi. Niekiedy pojawiają się próby takiego tłumaczenia, że wskutek pobytu na obczyźnie Mojżesz znajdował się na świętej ziemi ${ }^{55}$, której przysługiwała funkcja azylu, podobna do tej, którą pełniły tzw. miasta ucieczki (Lb 35,9-34 $)^{56}$. Powód zatem, dla którego Bóg próbował uśmiercić Mojżesza dopiero w jego drodze powrotnej do Egiptu, był taki, że dopiero w chwili wyruszenia z ziemi Madian opuścił on swój azyl, który do tej pory chronił go przed mścicielem.

Niektórzy egzegeci podają jeszcze inne argumenty mające przemawiać za takim tłumaczeniem przyczyny chęci uśmiercenia Mojżesza przez Boga. Ci badacze sugerują, że pojawiający się w 4,24 czasownik hāmît może przyjmować konotacje sądownicze związane z wykonywaniem wyroku. Podobnie pojawiający się w wypowiedzi Sefory rzeczownik „krew” (w. 25-26) w liczbie mnogiej może oznaczać „winę za przelanie krwi" ${ }^{\prime \prime}$. Warto wreszcie zauważyć, że występujący w 4,24 czasownik zbudowany na rdzeniu $b q s$ powraca również w 2,15 oraz 4,19, czyli w tych tekstach, gdzie także pojawia się motyw uśmiercenia kogoś ze względu na zaciągniętą winę.

Również ta propozycja egzegetów nie jest wolna od trudności. Przede wszystkim nie tłumaczy ona, jaki jest związek pomiędzy zaciągniętą przez Mojżesza winą a koniecznością obrzezania przez Seforę jednego z jej dzieci. Ciągle nie jest również jasne, dlaczego Sefora dwukrotnie powtórzyła wyrażenie hăatan-dämîm, jakie jest znaczenie tej frazy w samej narracji ani do kogo kieruje te słowa.

Mocną stroną takiego kierunku tłumaczenia Bożej interwencji w narracji 4,24-26 jest dobre osadzenie w wydarzeniach przedstawionych w początkowym kontekście Księgi Wyjścia. Problematyczne zachowanie Boga w świetle tej propozycji

55 Niekiedy w celu potwierdzenia takiego stanowiska przywołuje się tekst Wj 3,5.

56 Zob. Propp, Exodus 1-18, 235; Embry, „The Endangerment of Moses", 184.

57 Obie sugestie przywołuje: Propp, Exodus 1-18, 218, 234. 
zostaje przekonywująco wytłumaczone ${ }^{58}$. Sprecyzowany również zostaje desygnat kryjący się pod sufiksami zaimkowymi w 4,24 oraz osoba, która została dotknięta obciętym napletkiem - w obu przypadkach był to Mojżesz ${ }^{59}$.

\subsection{Niewłaściwa postawa Mojżesza podczas powołania}

Część badaczy przyczynę Bożej interwencji w drodze powrotnej Mojżesza do Egiptu proponuje wiązać z wydarzeniami mającymi miejsce podczas rozmowy powołanego z Bogiem na Horebie $(3,1-4,17)$. Egzegeci ci zwracają uwagę na przedstawienie Mojżesza od negatywnej strony przez narratora opisu powołania. Owa niewłaściwa postawa powołanego jest szczególnie widoczna w kilku miejscach opowiadania $(3,11.13 ; 4,1.10 .13)^{60}$. Na tle stosunkowo niewielkiej narracji ilość obiekcji, które wysunął Mojżesz, jest znacząca, przez co przyciąga uwagę czytelnika.

Mojżesz w różnoraki sposób próbował uwolnić się od zleconego mu zadania. Powoływał się na brak autorytetu $(3,11)$, nieznajomość powołującego go $(3,13)$, wyrażał zwątpienie w możliwość przekonania swoich pobratymców $(4,1)$ oraz odwoływał się do słabej elokwencji $(4,10)$. Gdy Bogu udało się przezwyciężyć wszystkie wysuwane przez Mojżesza obiekcje, ten, nie mając już innych argumentów, po prostu zasugerował, żeby Bóg znalazł kogoś innego w jego miejsce. Właśnie ta sugestia, jak stwierdza narrator, wywołała gniew Boży $(4,14)$. Część egzegetów proponuje zatem wiązać informacje $\mathrm{z}$ tego wiersza $\mathrm{z}$ wydarzeniem zrelacjonowanym w 4,24-26. Przy tej interpretacji Boża interwencja wynikała-

58 Oczywiście owo wyjaśnienie jest przekonywujące w świetle ówczesnych wierzeń.

59 Dotknięcie Mojżesza miałoby na celu przeniesienie „skuteczności” oczyszczającej mocy krwi z dziecka na ojca, by odpokutować winy tego drugiego. Zob. Propp, Exodus 1-18, 238.

60 Zob. Malina, „Dlaczego Bóg chciał zabić Mojżesza?”, 226. 
by z próby wychowania Mojżesza i przełamania jego oporu, który okazał podczas powołania ${ }^{61}$.

Słabą stroną przedstawionej propozycji wytłumaczenia powodu gniewu Bożego w kontrowersyjnej perykopie jest znikome powiązanie takiej interpretacji z dokonanym przez Seforę obrzezaniem. Nie wiadomo bowiem, dlaczego dotknięcie napletkiem nóg Mojżesza miałoby spowodować zmianę w Bożym zachowaniu do tego stopnia, że zrezygnował On z powziętego zamiaru. Taka propozycja nie tłumaczy również znaczenia wyrażenia hătan-dàmîm ani dlaczego zostało ono dwukrotnie przez Seforę powtórzone.

$\mathrm{Z}$ pewnością mocnym punktem przedstawionego tłumaczenia jest dobre osadzenie kontrowersyjnej perykopy w wydarzeniach opisanych w jej bliższym kontekście. Przy przyjęciu takiej interpretacji zrozumiałe się również staje, do kogo odnoszą się sufiksy zaimkowe z 4,24 oraz kogo Sefora dotknęła obciętym napletkiem. Samo wyjaśnienie przyczyny gniewu Bożego również wydaje się przekonywujące ${ }^{62}$.

\subsection{Antycypacja wydarzeń paschalnych}

Niektórzy badacze, szukając wytłumaczenia Bożej interwencji w perykopie 4,24-26, proponują odnosić się nie do wydarzeń poprzedzających powrót Mojżesza do Egiptu, jak to czyniły dotychczas przedstawione interpretacje, ale do zdarzeń następujących po kontrowersyjnej narracji. Przyjęcie odwróconej perspektywy interpretacyjnej zmusza do odczytywania interwencji Bożej z perykopy 4,24-26 w kluczu antycypacji późniejszych wydarzeń. Podstawowym punktem odniesienia dla egzegetów opowiadających się za tym stanowiskiem jest opis wydarzeń bezpośrednio poprzedzających wyjście narodu

61 Zob. Propp, Exodus 1-18, 196.

62 Wydaje się, że można również zaobserwować pewne podobieństwo tej sytuacji do przypadku Balaama. Ten wieszcz również wyruszył $\mathrm{w}$ drogę z polecenia Bożego, ale w drodze mógł zostać uśmiercony podobnie jak Mojżesz (Lb 22,2-35, zwł. 22,22.33). 
wybranego z Egiptu, czyli realizacja ostatniej plagi (śmierć pierworodnych), pomazanie przez Izraelitów drzwi domów krwią zabitego baranka oraz wieczerza paschalna (Wj 11,1-13,16).

Według tej propozycji związek pomiędzy epizodem w drodze powrotnej Mojżesza do Egiptu a wydarzeniami paschalnymi jest oparty przede wszystkim na motywie ostatniej plagi zesłanej przez Boga. Według informacji zawartych w 12,12-13.23 Bóg, przechodząc przez Egipt, miał uśmiercać wszystko, co pierworodne. Remedium na niszczycielską plagę miała być dla Izraelitów krew zabitego baranka, która chroniła ich od śmiertelnych skutków Bożego pochodu ${ }^{63}$. Zdaniem niektórych egzegetów Boża interwencja w perykopie 4,24-26 jest figurą owego pochodu ${ }^{64}$. Bóg zatem, zgodnie z tą interpretacją, chciał śmierci pierworodnego syna Mojżesza. Podobnie jak to miało mieć miejsce w przypadku Izraelitów, tak samo również i w odniesieniu do Mojżesza, aby oddalić od siebie śmiertelny pochód Boży, należało posłużyć się krwią. Właśnie dlatego Sefora musiała obrzezać swojego syna - nie tyle dla samego obrzezania, ile dla uzyskania materii potrzebnej do protekcji ${ }^{65}$.

Również i ta interpretacja nie jest wolna od trudności. Jedną z najbardziej podstawowych jest słabe powiązanie propozycji wyjaśnienia Bożej interwencji z dokonanym przez Seforę obrzezaniem ${ }^{66}$. Ta interpretacja nie tłumaczy również znaczenia frazy bătan-dāmîm ani sensu jej dwukrotnego powtórzenia przez małżonkę Mojżesza. Nie ma wreszcie

63 Zob. Smith, „Ethnological Parallels”, 14-15.

64 Por. Plastaras, The God of Exodus, 108.

65 Por. Propp, Exodus 1-18, 196; Maller, „The Bridegroom of Blood”, 94-98. Warto zauważyć, że Arabowie wykorzystywali krew podczas zawierania przymierza. Zob. Herodotus, Historiae, 3, 8.

66 W sposób naturalny pojawia się pytanie, czy rzeczywiście obrzezanie było jedynym sposobem na uzyskanie materii potrzebnej do ochrony syna Mojżesza, a jeśli nie, to dlaczego właśnie nim posłużyła się Sefora. 
absolutnej pewności, czyich nóg dotknęła Sefora obciętym napletkiem ani do kogo się zwróciła.

Dobrą stroną powyższej propozycji jest powiązanie narracji $4,24-26$ z jej kontekstem ${ }^{67}$. Przy przyjęciu tego tłumaczenia wiadomo, do kogo odnoszą się sufiksy zaimkowe z 4,24 oraz którego syna obrzezała Sefora ${ }^{68}$. W pewnym sensie takie rozwiązanie mogłoby również godzić ze sobą informacje z 4,20 oraz 18,1-6. Skoro bowiem Sefory i jej dzieci nie było w Egipcie podczas zsyłania plag, pierworodny syn Mojżesza nie mógł zostać ocalony wskutek pomazania drzwi domu krwią zabitego baranka. Ocalenie wskutek użycia krwi musiałoby się zatem dokonać w inny sposób ${ }^{69}$.

\section{Konkluzje}

Celem niniejszego opracowania była ocena najważniejszych interpretacji egzegetycznych usiłujących wytłumaczyć przyczynę gniewu Bożego w narracji Wj 4,24-26. Osiągnięcie postawionego celu pracy było możliwe dzięki odniesieniu poszczególnych propozycji egzegetów do konkretnych trudności generowanych przez kontrowersyjną perykopę. Umożliwiło to zaobserwowanie, $w$ jakim stopniu dana interpretacja roz- 
wiązuje wewnętrzne trudności narracji, a w jakim stopniu tego nie robi.

W świetle przeprowadzonych badań należy stwierdzić, że żadna z przeanalizowanych propozycji nie rozwiązuje w sposób satysfakcjonujący wszystkich problemów pojawiających się w perykopie. Za najlepszą w aspekcie tłumaczenia wewnętrznych trudności narracji należy uznać interpretację wiążącą Bożą interwencję z nieobrzezaniem jednego z bohaterów opowiadania. Należy jednak podkreślić, że nawet ta propozycja nie rozwiązuje wszystkich napięć wewnątrz samej perykopy i, co więcej, słabo wpisuje się w najbliższy kontekst narracji. Pozostałe interpretacje, chociaż wpisują się w mniejszym lub większym stopniu w kontekst opowiadania, to jednak w zdecydowanie mniejszym stopniu tłumaczą wewnętrzne trudności perykopy. Oznacza to, że żadne z tych wyjaśnień nie daje w pełni satysfakcjonujących odpowiedzi na postawiony w tytule opracowania problem, co zmusza egzegetów do dalszych poszukiwań.

\section{Bibliografia}

Allen R.B., „The «Bloody Bridegroom» in Exodus 4:24-26”, Bibliotheca Sacra 153 (1996) 259-269.

Ambrosius, In Psalmum David CXVIII Expositio (PL 15,1197-1526). Augustinus, Epistolae (PL 33,61-1094).

Augustinus, Quaestiones veteris et novi testamenti (PL 35,2214-2386). Augustinus, Quaestionum in Heptateuchum Libri Septem (PL 34,547-824).

Baranowski M., „Dlaczego Bóg chciał zabić Mojżesza (Wj 4,24)?”, Katecheta 57/7-8 (2013) 76-78.

Childs B.S., The Book of Exodus. A Critical, Theological Commentary (Louisville, KY: Westminster John Knox Press 2004).

Craghan J.F., Exodus (Collegeville, MN: Liturgical Press 1985). Dumbrell W., „Exodus 4:24-26: A Textual Re-Examination”, The Harvard Theological Review 65 (1972) 285-290. 
Embry B., „The Endangerment of Moses: Towards a New Reading of Exodus 4:24-26", Vetus Testamentum 60 (2010) 177-196.

Epiphanius, Panarion (PG 41,173-1200; PG 42,9-832).

Frolov S., „The Hero as Bloody Bridegroom: On the Meaning and Origin of Exodus 4,26", Biblica 77 (1996) 520-523.

Gregorius Nyssenus, De vita Moysis (PG 44,297-430); tt. polskie: Grzegorz z Nyssy, Życie Mojzesza (tł. S. Kalinkowski) (Źródła Myśli Teologicznej 50; Kraków: WAM 2009).

Herodotus, Historiae; tt. polskie: Herodot, Dzieje (tt. S. Hammer) (Warszawa: Czytelnik 2004).

Hippolytus, Commentarius in Danielem; za: Hippolyte, Commentaire surDaniel (tł.M.Lefèvre) (Sourceschrétiennes 14; Paris: Cerf 1947). Kłoczkowski A., „Dlaczego Bóg chciał zabić Mojżesza?”, Biblia krok po kroku 2/10 (2010) 9.

Lemański J., „Czy Jahwe rzeczywiście chciał zabić Mojżesza (Wj 4,24-26)?”, Żjemy dla Pana. Ksiega Pamiatkowa dedykowana S. Profesor Ewie Józefie Jezierskiej OSU w siedemdziesiata rocznice urodzin (red. M. Rosik) (Wrocław: Papieski Wydział Teologiczny we Wrocławiu 2005) 287-307. Lemański J., Księga Wyjścia. Wstęp. Przektad zoryginatu. Komentarz (Nowy Komentarz Biblijny. Stary Testament 2; Częstochowa: Edycja Świętego Pawła 2009).

Lemański J., „Szatan i inni. Kilka uwag o demonologii Starego Testamentu", Żywe jest Stowo Boże i skuteczne. Ksiega pamiatkowa dla Ks. Prof. Bernarda Wodeckiego SVD w50. rocznice święceń kaptańskich (red. W. Chrostowski) (Warszawa: Vocatio 2001) 165-190.

Łach S., Ksiega Wyjścia. Wstęp-przektad z oryginatu-komentarz (Pismo Swięte Starego Testamentu 2; Poznań: Pallottinum 1964).

Malina A., „Dlaczego Bóg chciał zabić Mojżesza? Egzegeza w kontekście Wj 4,24-26", Omnia tempus habent. Miscellanea theologica Vincentio Myszor quadragesimum annum laboris scientifici celebranti ab amicis, sodalibus discipulisque oblata (red. A. Reginek - G. Strzelczyk - A. Żądło) (Katowice: Wydział Teologiczny Uniwersytetu Śląskiego 2009) 218-229. 
Maller A.S., „The Bridegroom of Blood”, Jewish Bible Quarterly 21/2 (1993) 94-98.

Murphy R.E., The Book of Exodus (New York: Paulist Press 1962) I.

Origenes, Commentarium in epistolam beati Pauli ad Romanos (PG 14,837-1292); tł. polskie: Orygenes, Komentarz do Listu św. Pawta do Rzymian, Cz. 1 (tt. S. Kalinkowski) (Pisma Starochrześcijańskich Pisarzy 57; Warszawa: Akademia Teologii Katolickiej 1994).

Origenes, Contra Celsum (PG 11,637-1632).

Plastaras J., The God of Exodus (Milwaukee, WI: Bruce 1966).

Propp W.C., Exodus 1-18. A New Translation with Introduction and Commentary (New York, NY - London: Doubleday 1999). Propp W.H. „That Bloody Bridegroom (Exodus IV 24-6)”, Vetus Testamentum 43/4 (1993) 495-518.

Robinson B.P., „Zipporah to the Rescue: A Contextual Study of Exodus IV 24-6", Vetus Testamentum 36/4 (1986) 447-461.

Smith H.P., „Ethnological Parallels to Exodus iv. 24-26”, Journal of Biblical Literature 25/1 (1906) 14-24.

Tertullianus, Liber adversus Judaeos (PL 2,595-642).

Van Seters J., The Life of Moses. The Yahwist as Historian in ExodusNumbers (Kampen: Kok Pharos 1994).

Dawid Mielnik, absolwent teologii, filozofii, edytorstwa i informatyki, doktor nauk teologicznych w zakresie teologii biblijnej (KUL 2017), posiadacz międzynarodowego certyfikatu z zakresu grafiki komputerowej EITCA/CG, autor kilkunastu artykułów naukowych oraz monografii Saul u wróżki z Endor. Kulturowy i religijny kontekst nekromancji w ISm 28,3-25 (Warszawa: Warszawska Firma Wydawnicza 2014). Kilkukrotnie wyróżniony w konkursie „Studencki Nobel” na szczeblu lokalnym oraz ogólnopolskim, trzykrotny laureat ogólnopolskich olimpiad. 